\title{
Development and evaluation of taste masked dry syrup formulation of potassium chloride
}

\author{
Madhur Kulkarni ${ }^{1 *}$, Brijesh Vishwakarma², Samik Sen², Sandhya Anupuram and Abhijit A. Date ${ }^{3}$
}

\begin{abstract}
Potassium chloride $(\mathrm{KCl})$ syrup is widely used for the oral treatment of the hypokalemia. However, it is associated with unacceptable taste. In the present study, we sought to develop a palatable and easy to reconstitute $\mathrm{KCl}$ dry syrup as a commercially viable alternative to currently available $\mathrm{KCl}$ syrup. We explored the potential of Eudragit E100 as a taste-masking polymer to coat and improve the palatability of the $\mathrm{KCl}$. With the help of fluid bed processor, $\mathrm{KCl}$ was coated with the solution containing varying amounts of Eudragit $\mathrm{E} 100$ (4, 6, 10 and 15\%). Coating with $10 \%$ polymer solution enabled optimal fluid bed processing, higher entrapment of the $\mathrm{KCl}(81 \%)$ and better in vitro release profile in $0.1 \mathrm{~N} \mathrm{HCl}$ and pH 6.8 phosphate buffer. A dry syrup formulation containing Eudragit E100 coated $\mathrm{KCl}$ with good physical and chemical stability in dry and reconstituted state was developed. The palatability of the optimized formulation and commercially available $\mathrm{KCl}$ syrup was evaluated using the Electronic Taste Sensing Machine. The developed formulation showed 2-fold better taste-masking compared to the commercial $\mathrm{KCl}$ syrup. Thus, present investigation describes the development of an effective alternative to the current $\mathrm{KCl}$ syrup that can offer better palatability, stability and patient compliance.
\end{abstract}

Keywords: Taste masking, KCl, Eudragit E100, Fluid bed processing, Electronic taste sensing machine

\section{Introduction}

Hypokalemia is characterized by the potassium depletion from the body. Patients receiving diuretics treatment, those suffering from diabetic ketoacidosis or primary and secondary hyperaldosteronism often experience hypokalemia (Cohn et al., 2000). Potassium depletion due to these causes is usually accompanied by a concomitant loss of chloride. Potassium chloride $(\mathrm{KCl})$ is an electrolyte of choice for the treatment of hypokalemia as it can replenish potassium as well as chloride ions in the patients experiencing hypokalemia (Shen, 1996; Gennari, 1998). Patients with hypokalemia typically require a dose between 40 and $100 \mathrm{mEq}$ of potassium per day. The US FDA has approved a number of immediate and extended release $\mathrm{KCl}$ formulations which contain a relatively high amount of $\mathrm{KCl}(600-1500 \mathrm{mg})$ to meet the daily

\footnotetext{
* Correspondence: madhur.kulkarni@indiraicp.edu.in

${ }^{1}$ Department of Pharmaceutics, SCES's Indira College of Pharmacy, 89/2a,

Niramay, New Mumbai Pune Highway, Tathawade, Pune, Maharashtra

411033, India

Full list of author information is available at the end of the article
}

requirement (Mittapalli et al., 2017). Due to a relatively high dose of $\mathrm{KCl}$, these formulations are bulky and are difficult to swallow especially for the paediatric and geriatric population.

Another issue with oral $\mathrm{KCl}$ therapy is its very unacceptable taste which often leads to nausea and vomiting. Furthermore, sudden availability of large dose of $\mathrm{KCl}$ also leads to gastric irritation which further exacerbates nausea and vomiting (Mcmahon et al., 1982). The film coated tablets and extended release capsule and tablet formulations minimize this side effect (Wu et al., 2003; Graham et al., 1990; Chang and Rudnic, 1991; Kumar et al., 2011). However, these formulations are not very suitable for paediatric and geriatric patients. Furthermore, in India, only $\mathrm{KCl}$ syrup and solutions are available to the patients (CIMS, 2017) and these formulations have very unacceptable taste. Here, we report the development of $\mathrm{KCl}$ dry syrup with improved palatability. To improve the palatability of $\mathrm{KCl}$, we directly coated pure $\mathrm{KCl}$ crystals with Eudragit E 100, a pH sensitive amino alkyl methacrylate copolymer by means of fluid bed processing. This strategy 
masked the salty taste of $\mathrm{KCl}$ and prevented its instantaneous release in the stomach. This simple and commercially viable approach is expected to significantly improve compliance and acceptability of $\mathrm{KCl}$ syrup formulations in the patients especially in the paediatric and geriatric population.

\section{Materials and methods}

\section{Materials}

$\mathrm{KCl}$, sucralose and cherry flavour, methyl paraben and propyl paraben were purchased from Analab Fine chem, Ltd., Pune, India. Talc (Luzenac pharma $\mathrm{M}$ ) and titanium dioxide (Kronos 1171) were purchased from Signet Chemicals, Mumbai, India. Triethyl citrate was purchased from Loba Chemie, Mumbai, India. Silver nitrate $\left(\mathrm{AgNO}_{3}\right)$ was purchased from Merck chemicals, Mumbai. India. Eudragit ${ }^{\circ} \mathrm{E}$ 100 (copolymer of dimethyl aminoethyl methacrylate, butyl methacrylate, and methyl methacrylate) was obtained as a gift sample from Evonik Industries, Mumbai, India. Avicel ${ }^{\circ}$ CL 611 (Microcrystalline cellulose and carboxy methyl cellulose) was purchased from Hiranya cellulose products, Mumbai, India.

\section{Fluid bed coating}

\section{Preparation of coating solution}

The coating solution was prepared by dissolving Eudragit E100 in the mixture of isopropyl alcohol and acetone (60:40 ratio). Triethyl citrate (plasticizer) was added and dissolved in the solution of polymer. Talc (anti-adherent) and titanium dioxide (opacifier) were passed through $80 \#$ sieve and dispersed slowly into the Eudragit solution under stirring to form a uniform suspension (Table 1). The suspension was stirred for $30 \mathrm{~min}$ before beginning the coating process and then throughout the coating to avoid settling of suspended solids.

\section{Coating trials}

The coating was performed on $400 \mathrm{~g}$ batch size of $\mathrm{KCl}$ using a fluidized bed Wurster coater (Gansons, India, GFBPC 2 l) inserted with one Wurster column employing bottom spray. The coating procedure involved maintaining

Table 1 Compositions of coating solutions used for fluid bed coating of $\mathrm{KCl}$

\begin{tabular}{lllll}
\hline Excipient & \multicolumn{4}{l}{ Composition (\%w/w) } \\
\cline { 2 - 5 } & C1 & C2 & C3 & C4 \\
\hline Eudragit E100 & 4 & 6 & 10 & 15 \\
Talc & 0.24 & 0.36 & 0.6 & 0.9 \\
Triethyl citrate & 0.14 & 0.21 & 0.35 & 0.52 \\
Titanium dioxide & 0.08 & 0.12 & 0.2 & 0.3 \\
$\begin{array}{l}\text { Isopropyl alcohol + acetone } \\
\text { mixture }\end{array}$ & q.s. 100 & q.s. 100 & q.s. 100 & q.s. 100 \\
\hline
\end{tabular}

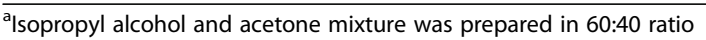

the bed temperature at 40 to $43^{\circ} \mathrm{C}$, spray rate of $16 \mathrm{~g} / \mathrm{min}$, blower rpm of 800 , inlet air pressure of $5.4 \mathrm{Kg} / \mathrm{cm}^{2}$, inlet air temperature of $50^{\circ} \mathrm{C}$ exhaust temperature of $33^{\circ} \mathrm{C}$ and atomizing air pressure in the region of 1.8 to $2.2 \mathrm{bar}$. In all, 4 lots of $\mathrm{KCl}$ were coated using solutions containing $4 \%$, $6 \%, 10 \%$ and $15 \%$ of Eudragit E 100. The coated samples were termed as $\mathrm{C} 1, \mathrm{C} 2, \mathrm{C} 3$ and $\mathrm{C} 4$ respectively.

\section{Evaluation of coated $\mathrm{KCl}$ \\ Assay}

The drug content of coating compositions was determined by titrimetric assay (Indian pharmacopeia, 2014).The sample of coated $\mathrm{KCl}$ equivalent to $150 \mathrm{mg}$ of $\mathrm{KCl}$ was crushed in a mortar and dissolved in $50 \mathrm{~mL}$ of distilled water. Further, 2 drops of potassium chromate indicator were added and titrated with the $0.1 \mathrm{~N} \mathrm{AgNO}_{3}$. The endpoint was dark red brownish color. The assay was done in triplicate.

\section{Entrapment efficiency}

\% Entrapment efficiency $=[$ Drug added - unentrapped drug)/Drug added] "100.

Coated $\mathrm{KCl}, 1 \mathrm{~g}$ was added to $50 \mathrm{~mL}$ of $\mathrm{pH} 6.8$ buffer and gently stirred for $2 \mathrm{~min}$. The dispersion was filtered and filtrate was titrated with $0.1 \mathrm{~N} \mathrm{AgNO}_{3}$ in similar manner as described in the Assay section above.

\section{In vitro drug release studies}

The in vitro drug release profiles of compositions C1-C4 each equivalent to $500 \mathrm{mg}$ of $\mathrm{KCl}$ were determined using $900 \mathrm{~mL}$ of phosphate buffer pH 6.8 maintained at $37 \pm 0.5^{\circ} \mathrm{C}$. The paddles of USP Type II apparatus (TDL $06 \mathrm{~L}$, Electrolab, India)were stirred at $50 \mathrm{rpm}$ and 5 $\mathrm{mL}$ aliquots were withdrawn at $5,10,15,30 \mathrm{~min}$ intervals and the equal amount of fresh medium was replaced. The amount of drug released was determined by titrimetric assay wherein $5 \mathrm{ml}$ of aliquot was made up to $50 \mathrm{~mL}$ with distilled water and the solution was titrated against $0.1 \mathrm{~N}$ $\mathrm{AgNO}_{3}$ using potassium chromate indicator. Similar study was performed on all the coated compositions by using 0.1 $\mathrm{N}$ hydrochloric acid $(\mathrm{HCl})$ as a dissolution medium.

\section{Particle size}

Particle size of composition C3 was determined by microscopy technique (Labomed Lx 300 equipped with Image Pro Premier software, USA). The smear of aqueous dispersion of sample was observed under 10X magnification and size of particles from at least 20 fields was noted.

\section{Flow properties}

Composition C3 was subjected to determination of angle of repose and Hausner ratio by reported methods (Khar et al., 2013). 


\section{Microscopy}

Pure $\mathrm{KCl}$ and the samples of composition $\mathrm{C} 2$ and $\mathrm{C} 3$ were observed under microscope (Labomed Lx 300, USA) for morphology. Photomicrographs of the fields were taken.

\section{Scanning electron microscopy (SEM)}

The surface characteristics of composition $\mathrm{C} 2$ and $\mathrm{C} 3$ were examined by means of a scanning electron microscope (Quanta-200, Thermo Fischer Scientific, USA). The double-sided carbon tape was placed on aluminum stab. The stab was dipped in the sample and with the help of air blower, loose particles were removed. The sample was coated with gold particles by using bio-radpolaran sputter coater. The sample was placed in an evacuated chamber and was scanned in a controlled pattern by electron beam. Images of plain $\mathrm{KCl}$ and that of the coated ones were compared with each other.

\section{Development and evaluation of dry syrup formulations}

All the ingredients were passed through 30\# sieve and weighed accurately (Table 2). Sucralose, cherry flavor, methyl paraben and propyl paraben were mixed together and the mixture was added to rest of the bulk by geometric mixing. All the ingredients were mixed thoroughly in a polythene bag for 5-7 min. The formulation was then filled in the glass bottles marked with $30 \mathrm{~mL}$ volume and stored at room temperature until further evaluation.

\section{Organoleptic evaluation}

The formulations were subjected to visual and olfactory examination.

\section{Flow properties}

Angle of repose and Hausner ratio of the dry syrup formulations were determined.
The dry syrup formulations were reconstituted by adding distilled water up to $30 \mathrm{~mL}$ mark in the bottle. The contents were mixed well by shaking, poured in a measuring cylinder and subjected to the following evaluation on day $1,2,3$ and 7 of reconstitution.

\section{Appearance}

The reconstituted formulations were observed for appearance, colour and texture.

\section{Redispersibility test}

The redispersibility of the suspensions was checked by inverting the cylinder upside down until there was no sediment at the bottom of the cylinder.

\section{Sedimentation volume}

Suspension of each formulation was kept standing undisturbed at room temperature. The volume of sediment was noted on day $1,2,3$ \& 7 of reconstitution and the sedimentation ratio was calculated (Aulton, 2013).

\section{Assay}

The assay of reconstituted suspension of formula F8 was determined by titrimetry. About $1.5 \mathrm{~mL}$ of reconstituted suspension equivalent to $150 \mathrm{mg}$ of $\mathrm{KCl}$ was triturated and dispersed in $50 \mathrm{~mL}$ distilled water. The suspension was titrated against $0.1 \mathrm{~N} \mathrm{AgNO}_{3}$ using potassium chromate as an indicator until the sample turned reddish brown. The assay was done in triplicate. The assay was repeated on day $1,2,3$ and 7 of reconstitution.

\section{In vitro release studies}

The in vitro drug release from formulation F8was studied separately in $0.1 \mathrm{~N} \mathrm{HCl}$ and in $\mathrm{pH} 6.8$ phosphate buffer in the manner similar to the one described in the evaluation

Table 2 Trials for the development of dry syrup formulation of coated $\mathrm{KCl}$ composition

\begin{tabular}{|c|c|c|c|c|c|c|c|c|}
\hline \multirow[t]{2}{*}{ Ingredients } & \multicolumn{8}{|c|}{ Quantity in g } \\
\hline & $\mathrm{F} 1$ & $\mathrm{~F} 2$ & F3 & $\mathrm{F} 4$ & F5 & F6 & F7 & F8 \\
\hline Composition $C 3^{\mathrm{a}}$ & 6.6 & 6.6 & 6.6 & 6.6 & 6.6 & 6.6 & 6.6 & 6.6 \\
\hline Xanthan gum & 0.3 & - & - & - & - & - & - & - \\
\hline HPMC K 100LV & - & 0.3 & - & - & - & - & - & - \\
\hline Sodium carboxy methyl cellulose & - & - & 0.3 & - & - & - & - & - \\
\hline Avicel CL 611 & - & - & - & 0.3 & 0.6 & 1.0 & 1.5 & 3 \\
\hline Sucralose & 0.03 & 0.03 & 0.03 & 0.03 & 0.03 & 0.03 & 0.03 & 0.03 \\
\hline Disodium citro- phosphate & 1.76 & 1.76 & 1.76 & 1.76 & 1.76 & 1.76 & 1.76 & 1.76 \\
\hline Citric acid & 0.11 & 0.11 & 0.11 & 0.11 & 0.11 & 0.11 & 0.11 & 0.11 \\
\hline Cherry flavor & 0.03 & 0.03 & 0.03 & 0.03 & 0.03 & 0.03 & 0.03 & 0.03 \\
\hline Methyl paraben & 0.1 & 0.1 & 0.1 & 0.1 & 0.1 & 0.1 & 0.1 & 0.1 \\
\hline Propyl Paraben & 0.01 & 0.01 & 0.01 & 0.01 & 0.01 & 0.01 & 0.01 & 0.01 \\
\hline Total & 8.94 & 8.94 & 8.94 & 8.94 & 9.24 & 9.64 & 10.14 & 11.64 \\
\hline
\end{tabular}

${ }^{a}$ Composition $\mathrm{C} 3$ is $\mathrm{KCl}$ coated with $10 \%$ w/w Eudragit E 100 solution 
of coated $\mathrm{KCl}$ compositions. The release studies were performed on day 1, 2, 3 and 7 of reconstitution.

Kesol syrup batch no KSL1644, (Mfg-Oct 2016- Exp-Sep 2019) was procured from the local pharmacy and subjected to in vitro drug release studies using $0.1 \mathrm{~N} \mathrm{HCl}$ as a dissolution medium. The release profile of formulation F8 was compared with that of the marketed formulation.

\section{Evaluation of taste using electronic taste sensing machine}

Reconstituted suspension of formulation F8 and the marketed syrup formulation were coded as $\mathrm{K} 1$ and $\mathrm{K} 2$ respectively. At S. Zhaveri and Company, Mumbai, the formulations were subjected to the analysis of taste using Electronic taste sensing machine (TS-5000Z, Japan). Bitter sensor and salty sensor were used in the study. Reference electrode and sensor were initially dipped in a beaker containing a reference solution which comprised of 30 $\mathrm{mM} \mathrm{KCl}$ and $0.3 \mathrm{mM}$ tartaric acid. Potentiometric difference between each sensor and a reference electrode was measured and recorded by the E-tongue software (Linux) in terms of $\mathrm{mV}$. For reference solution the output was termed as Vr. Similarly, membrane potentials Vs and Vt respectively for the marketed formulation and formulationF8 were obtained. The difference between sample and reference viz. $\mathrm{Vs}-\mathrm{Vr}$ and $\mathrm{Vt}-\mathrm{Vr}$ was compared (Keating et al., 2017; Latha \& Lakshmi, 2012; Lorenz et al., 2009).

\section{Stability studies of optimized dry syrup formulation}

Dry syrup formulation was prepared in bulk using the composition of formulation F8 (containing optimized concentration of suspending agent Avicel CL 611). The appropriate quantity was filled in each glass bottle, capped, sealed and subjected to accelerated storage conditions of $40 \pm 2{ }^{\circ} \mathrm{C} / 75 \pm 5 \% \mathrm{RH}$ for the period of three months. The samples were withdrawn at one, two and three-month intervals and subjected to all the tests mentioned in the section of evaluation of dry syrup formulations.

\section{Results}

Fluid bed coating of $\mathrm{KCl}$ with Eudragit E100

Compositions $\mathrm{C} 1, \mathrm{C} 2, \mathrm{C} 3$ and $\mathrm{C} 4$ of coated $\mathrm{KCl}$ were obtained by using 4, 6, 10 and 15\% $w / \mathrm{w}$ Eudragit E100 solutions respectively. Though $\mathrm{KCl}$ is thermostable, the temperature of the fluid bed was kept below $45^{\circ} \mathrm{C}$ to avoid exceeding glass transition temperature $(\mathrm{Tg})$ of Eudragit $\mathrm{E}$ $\left(\mathrm{Tg}-45-50^{\circ} \mathrm{C}\right)$ (Malik et al., 2011). Compositions C1-C3 (Eudragit E100: 4-10\%) did not encounter any problems during fluid bed processing whereas fluid bed processing of composition C4 (15\% Eudragit E100) resulted in the sticking of powder particles to the walls of fluid bed processor which resulted in the decrease in fluidization and overall inefficient coating process.

\section{Evaluation of coated $\mathrm{KCl}$}

\section{Assay, in vitro $\mathrm{KCl}$ release and micromeritics of} compositions $\mathrm{C1}$ - C4

Assay of all the compositions of coated $\mathrm{KCl}$ was in the range of 98 to $101 \%$. Entrapment efficiency for composition C1-C4 was found to be $69.2 \pm 0.3,74.5 \pm 0.2,81.1 \pm 0.4$ and $84 \pm 0.4 \%$ respectively indicating greater encapsulation efficiency of $\mathrm{KCl}$ with increase in the level of Eudragit E100 concentration in the coating trials.

The in vitro release profiles of all the compositions are depicted in Table 3.

Compositions $\mathrm{C} 1$ and $\mathrm{C} 2$ showed more than $90 \%$ release in acidic medium within first 15 min as compared to composition C3 which showed almost complete release at the end of $30 \mathrm{~min}$. Composition C4 could retard the release to a greater extent but had shown sticking problem during coating process.

The release studies of coated $\mathrm{KCl}$ were also done in pH 6.8 phosphate buffer ( saliva $\mathrm{pH})$. In case of compositions, $\mathrm{C} 1$ and $\mathrm{C} 2$, more than $20 \%$ release was observed at the end of $30 \mathrm{~min}$ whereas, compositions $\mathrm{C} 3$ and $\mathrm{C} 4$ (containing higher \% of Eudragit E100) showed about 15 and $10 \%$ release respectively. This indicated better coating efficiency of composition C3 and C4 with lesser extent of drug release in saliva and thus better masking of the taste. Composition C3 was selected for the further studies as it showed optimum encapsulation, no issues in the fluid bed processing, absence of burst release in the stomach and saliva $\mathrm{pH}$ values.

Since the aim of the present work was to develop a dry syrup formulation, evaluation of micromeritic properties of the powder was important to understand the ease of handling and filling of the formulation. Composition C3 showed the average particle size of $316.2 \pm 29.4 \mu \mathrm{m}$, angle of repose of $35^{\circ}$ and Hausner ratio of 1.2. Both the

Table 3 In vitro release studies of various coated compositions of $\mathrm{KCl}$

\begin{tabular}{|c|c|c|c|c|c|c|c|c|}
\hline \multirow{2}{*}{$\begin{array}{l}\text { Time } \\
\text { Min }\end{array}$} & \multicolumn{4}{|c|}{ \%Cumulative $\mathrm{KCl}$ Release $(0.1 \mathrm{NHCl})$} & \multicolumn{4}{|c|}{ \%Cumulative KCl Release (pH 6.8 phosphate buffer) } \\
\hline & $\mathrm{C} 1$ & $\mathrm{C} 2$ & C3 & C4 & C1 & $\mathrm{C} 2$ & $\mathrm{C} 3$ & C4 \\
\hline 5 & $56.0 \pm 1.3$ & $51.9 \pm 1.6$ & $53.3 \pm 4.5$ & $42.8 \pm 2.9$ & $9.94 \pm 2.2$ & $8.94 \pm 2.6$ & $5.96 \pm 1.5$ & $3.47 \pm 4.3$ \\
\hline 10 & $73.0 \pm 1.3$ & $79.1 \pm 3.0$ & $63.11 \pm 2.3$ & $58.4 \pm 5.1$ & $13.41 \pm 3.5$ & $11.43 \pm 1.4$ & $8.44 \pm 2.3$ & $5.96 \pm 2.5$ \\
\hline 15 & $89.1 \pm 2.2$ & $87.2 \pm 1.2$ & $72.3 \pm 3.6$ & $65.2 \pm 2.3$ & $16.40 \pm 4.4$ & $14.91 \pm 3.7$ & $9.43 \pm 3.0$ & $6.95 \pm 4.5$ \\
\hline 30 & $98.8 \pm 2.1$ & $92.6 \pm 3.1$ & $95.8 \pm 2.9$ & $86.9 \pm 2.8$ & $28.86 \pm 2.4$ & $23.90 \pm 3.4$ & $15.93 \pm 2.5$ & $9.46 \pm 4.7$ \\
\hline
\end{tabular}

All the values are average \pm standard deviation of $n=6$ 
parameters indicated good flow characteristics of the composition (Khar et al., 2013). Too small particles may affect the flow of the powders while coarser particles would have unacceptable mouth-feel. Composition C3 with optimum particle size and passable flow properties was considered suitable for the formulation development.

\section{Microscopic evaluation}

The microscopic examination of uncoated $\mathrm{KCl}$ showed the presence of shiny and almost transparent crystals of $\mathrm{KCl}$ (Fig. 1a). Particles of composition C2 coated with $6 \%$ polymer solution showed opaque appearance interspersed with shiny spots indicating partially uncoated $\mathrm{KCl}$ (Fig. 1b) whereas particles of composition C3 coated with 10\% solution showed uniform, opaque image with relatively lesser number of uncoated particles (Fig. 1c). SEM image of composition C3 distinctly showed dark coloured coating on the brighter drug particles (Fig. 2a) whereas the extent of coating was lesser in case of particles of composition C2 (Fig. 2b). Pure drug particles appear whitish with very irregular surface morphology (Fig. 2c). Microscopy studies thus indicated a direct proportion in the extent of coating with increasing concentration of Eudragit E100 in coating solution.

\section{Development and evaluation of dry syrup formulations}

Formulation trials were taken using various suspending agents like xanthan gum, HPMC K100 LV, sodium carboxy methyl cellulose, and Avicel CL 611 (Table 2). Cherry flavor along with sucralose as a sweetener imparted pleasant organoleptic properties to the formulation. Disodium citrophosphate and citric acid maintained the formulation $\mathrm{pH}$ at 7 upon reconstitution. The resulting formulations in dry state and upon reconstitution were subjected to various evaluation parameters. Observations of these are given in Table 4.

Formulations F1 to F8 are the trial dry syrup formulations prepared with various suspending agents like F1 with $3.3 \%$ guar gum, F2 with 3.3\% HPMC K 100LV, F3 with $3.3 \%$ sodium carboxymethyl cellulose, F4, F5, F6, F7 and F8 with $3.3 \%, 6.5 \%, 10 \%, 15 \%$ and $26 \% w / w$ Avicel CL 611 respectively.

\section{In vitro release studies of reconstituted suspension}

The results of drug release studies of formulation F8 on day 1, 2, 3 and 7 of reconstitution are given in Table 5.

The graph showing comparison of drug release from formulation $\mathrm{F} 8$ in $0.1 \mathrm{~N} \mathrm{HCl}$ on day 1 and that of marketed preparation is shown in (Fig. 3).

\section{Taste evaluation using electronic taste sensing machine}

During taste analysis, salty sensor gave better response than the bitter sensor. The software computed the sensory output in terms of change in the membrane potential of sensor as compared to the reference electrode. The difference between the potential shown by developed formulation and the reference solution was of $15 \mathrm{mV}$ whereas that
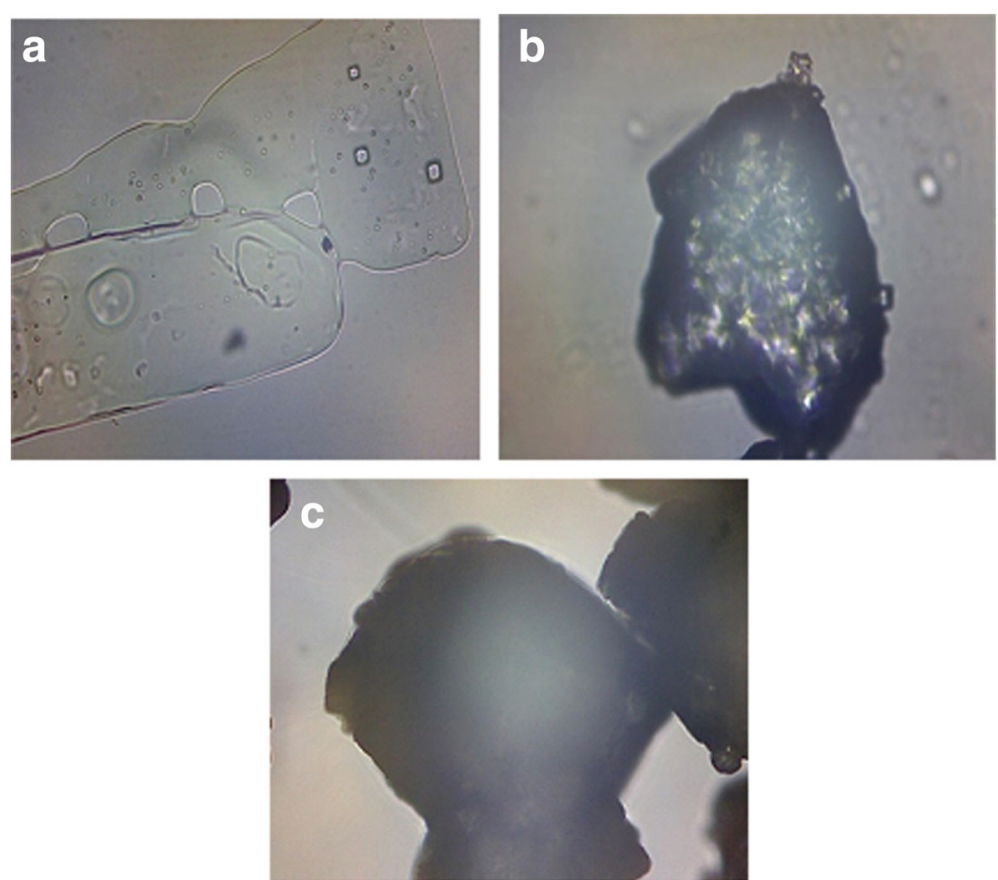

Fig. 1 Photomicrographs of a Uncoated $\mathrm{KCl}$ b Composition C2 of $\mathrm{KCl}$ coated with 6\% Eudragit E 100 solution c Composition C3 of $\mathrm{KCl}$ coated with 10\% Eudragit E 100 solution 

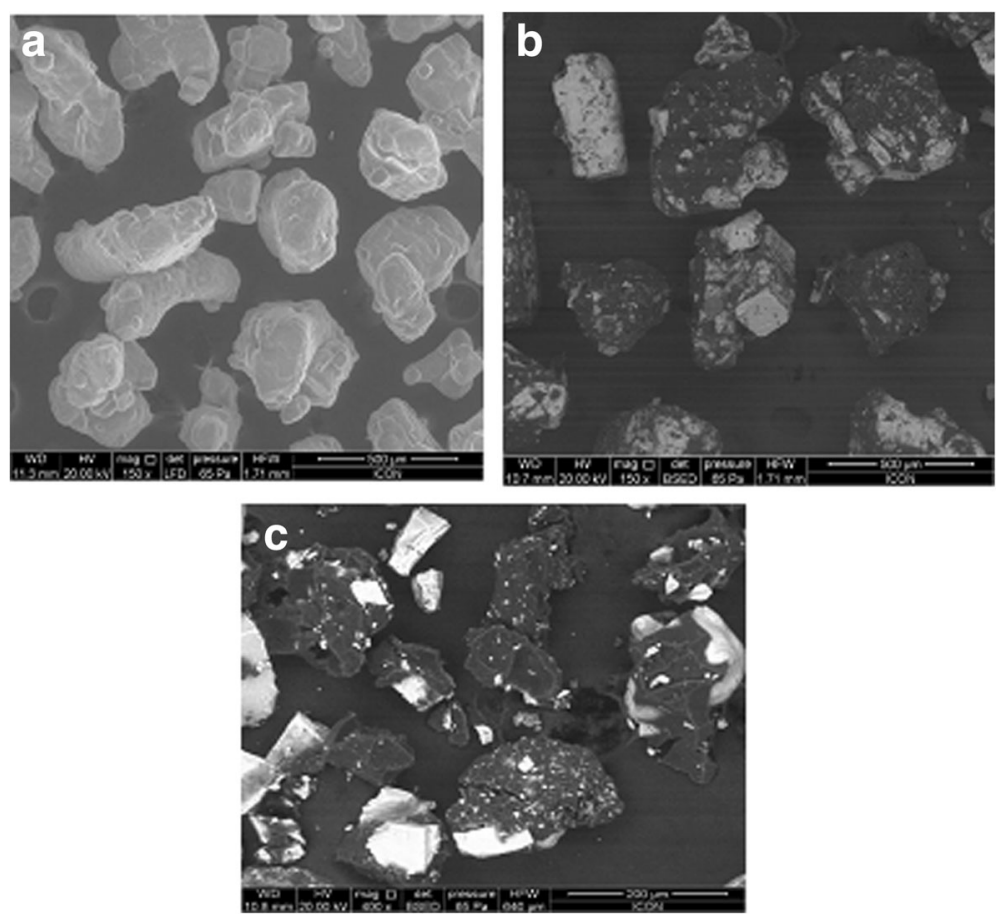

Fig. 2 SEM images of a Uncoated $\mathrm{KCl}$ b Composition C2 of $\mathrm{KCl}$ coated with 6\% Eudragit E 100 c Composition C3 of $\mathrm{KCl}$ coated with 10\% Eudragit E 100 solution

between the marketed formulation and reference solution was $32.5 \mathrm{mV}$ which indicates that the taste was masked $\sim 2$-fold better in case of developed formulation as compared to the marketed formulation.

\section{Stability studies of optimized dry syrup formulation}

Accelerated stability studies showed good physical stability of the formulation in dry as well reconstituted state.
No significant difference was observed in assay and drug release profiles of stability samples (Table 6).

\section{Discussion}

Currently, $\mathrm{KCl}$ syrup is the only option available in India for paediatric and geriatric patients. The taste of this formulation is considered unacceptable clinically. While developing liquid oral formulations, taste masking of a drug is of paramount importance to enhance acceptance and

Table 4 Evaluation of dry syrup formulations of composition C3 of coated $\mathrm{KCl}$

\begin{tabular}{|c|c|c|c|c|c|c|c|}
\hline \multirow[b]{2}{*}{ Formulation } & \multicolumn{2}{|l|}{ Dry form } & \multirow[b]{2}{*}{ Appearance } & \multicolumn{4}{|c|}{ Reconstituted form } \\
\hline & Angle of repose $\left(^{0}\right)$ & Hausner ratio & & $\overline{\mathrm{pH}}$ & Redispersibility & $\begin{array}{l}\text { Sedimentation } \\
\text { ratio }\end{array}$ & Assay $^{a}$ \\
\hline F1 & 35.3 & 1.23 & White -to -off white, phase separation & 7.1 & 9 & 0.66 & $99.4 \pm 0.2$ \\
\hline F2 & 35.5 & 1.22 & White -to -off white, homogeneous suspension & 7.0 & 8 & 0.73 & $97.6 \pm 0.6$ \\
\hline F3 & 35.2 & 1.22 & $\begin{array}{l}\text { White -to- off white, homogeneous } \\
\text { suspension }\end{array}$ & 7.0 & 7 & 0.73 & $96.9 \pm 0.8$ \\
\hline F4 & 35.2 & 1.22 & $\begin{array}{l}\text { White -to -off white, homogeneous } \\
\text { suspension }\end{array}$ & 7.0 & 6 & 0.70 & $96.9 \pm 0.7$ \\
\hline F5 & 35.1 & 1.21 & White -to -off white, phase separation & 7.0 & 6 & 0.80 & $98.6 \pm 0.4$ \\
\hline F6 & 35 & 1.22 & $\begin{array}{l}\text { White -to -off white, homogeneous } \\
\text { suspension }\end{array}$ & 7.0 & 5 & 0.83 & $97.5 \pm 0.1$ \\
\hline F7 & 33.4 & 1.16 & $\begin{array}{l}\text { White -to- off white, homogeneous } \\
\text { suspension }\end{array}$ & 7.0 & 4 & 0.86 & $98.8 \pm 0.8$ \\
\hline F8 & 31.8 & 1.15 & $\begin{array}{l}\text { White -to -off white, homogeneous } \\
\text { suspension }\end{array}$ & 7.0 & 2 & 0.91 & $96.9 \pm 0.5$ \\
\hline
\end{tabular}

${ }^{a}$ the assay values shown are average \pm standard deviation of $n=3$ 
Table 5 In vitro release studies of reconstituted formulation F8 on day 1, 2, 3 and 7 of reconstitution

\begin{tabular}{|c|c|c|c|c|c|c|c|c|}
\hline \multicolumn{9}{|c|}{$\%$ Cumulative release } \\
\hline \multirow[b]{2}{*}{ Time(min) } & \multicolumn{4}{|l|}{$0.1 \mathrm{~N} \mathrm{HCl}$} & \multicolumn{4}{|c|}{ pH 6.8 Phosphate buffer ${ }^{a}$} \\
\hline & 1st day & 2nd day & $3 r d$ day & 7th day & 1st day & 2nd day & $3 r d$ day & 7th day \\
\hline 5 & $56.6 \pm 0.3$ & $57.1 \pm 0.2$ & $56.1 \pm 0.2$ & $73.0 \pm 0.3$ & $2.8 \pm 0.5$ & $5.6 \pm 0.2$ & $6.8 \pm 0.9$ & $10.3 \pm 0.2$ \\
\hline 10 & $67.0 \pm 0.8$ & $66.4 \pm 0.3$ & $65.0 \pm 0.5$ & $82.9 \pm 0.2$ & $5.65 \pm 0.2$ & $6.9 \pm 0.3$ & $7.7 \pm 0.2$ & $12.3 \pm 0.3$ \\
\hline 15 & $83.4 \pm 0.3$ & $80.5 \pm 0.6$ & $81.0 \pm 0.3$ & $96.9 \pm 0.1$ & $8.48 \pm 0.4$ & $8.5 \pm 0.8$ & $8.2 \pm 0.2$ & $15.8 \pm 0.2$ \\
\hline 30 & $98.4 \pm 0.1$ & $95.4 \pm 0.1$ & $94.3 \pm 0.2$ & $99.8 \pm 0.3$ & $13.6 \pm 2.9$ & $13.8 \pm 0.4$ & $15.9 \pm 2.6$ & $20.3 \pm 1.2$ \\
\hline
\end{tabular}

alower drug release in $\mathrm{pH} 6.8$ Phosphate buffer indicates better efficiency of coating of $\mathrm{KCl}$ with Eudragit $\mathrm{E} 100$ and hence better taste masking. All the values are average \pm standard deviation of $n=6$

compliance to the therapy by the patient (Faisal et al., 2018; Kaushik \& Dureja, 2014). Depending on the extent of unacceptable taste, various approaches like addition of sweeteners, flavoring agents and viscosity builders (Thoke et al., 2012), complexation with cyclodextrins (Mahesh et al., 2010; Dinge \& Nagarsenker, 2008; Prabhakaran et al., 2016), granulation (Pawar \& Joshi, 2014), spray drying (Amelian et al., 2017a), ion exchange resins (Kouchak et al., 2018), hot melt extrusion (Pimparade et al., 2015) or conversion to a prodrug (Karaman, 2013) are employed for the taste-masking. Microencapsulation is one of the leading techniques for the taste-masking of a variety of drugs. Microencapsulation creates a physical barrier between the drug and the taste receptors in the form of a polymeric film thus leading to efficient taste masking. Although there are several ways to achieve microencapsulation, fluid bed processing is one of the most efficient, fast and economic techniques to achieve microcapsules with high yield, uniform coating and better entrapment efficiency leading to improved taste masking (Stange et al., 2014; Keser et al., 2018; Ghimire et al., 2018). In the present study, we sought to develop dry syrup formulation containing microencapsulated $\mathrm{KCl}$ which would not only mask the taste but also offer the advantages such as convenience of handling, lesser weight

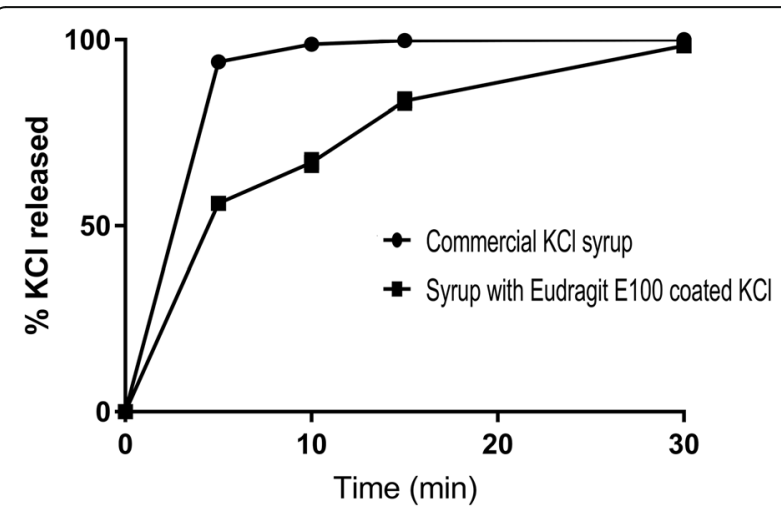

Fig. 3 Comparison ofin vitro dissolution profiles of marketed syrup formulation and reconstituted formulation F8. The observations are average \pm standard deviation of $n=6$ (The error bars are not visible in the figure owing to standard deviation values less than 2) per container and overall better stability. We explored the potential of Eudragit E100 to coat and mask the taste of highly crystalline inorganic salts such as $\mathrm{KCl}$ which is hitherto not reported. We used commercially viable technique such as fluid bed coating to achieve Eudragit E100 coating. Eudragit E100 is a cationic amino alkyl methacrylate copolymer which solubilizes below $\mathrm{pH}$ 5.5 but remains insoluble at $\mathrm{pH}$ greater than 5.5. These solubility characteristics make it ideal for taste masking applications wherein the polymer would not dissolve in saliva (pH- 6.8 to 7.4 ) thus maintaining the physical barrier between the drug and the taste buds. Upon entering the stomach, it would dissolve in gastric fluids thus releasing the drug. It is safe for oral consumption and approved by the regulatory authorities (Rowe et al., 2009; Maniruzzaman et al., 2012). A number of reported studies have used this polymer for taste masking of

Table 6 Accelerated stability study of formulation F8

\begin{tabular}{lll}
\hline Sampling Interval & Parameters & Observations \\
\hline 1 month & Appearance & $\begin{array}{l}\text { White-to- off white, } \\
\text { smooth, suspension }\end{array}$ \\
& Taste on day 1,2,3,7 & Pleasant \\
& pH on day 1,2,3,7 & $6.7-6.8$ \\
& Sedimentation volume & 0.86 \\
2 month & Assay on day 1,2,3,7 & $99.5-99.1$ \\
& Appearance & White-to- off white, \\
& & smooth, suspension \\
& Taste on day 1,2,3,7 & Pleasant \\
pH on day 1,2,3,7 & $6.7-6.8$ \\
& Sedimentation volume & 0.85 \\
& Assay & $97.4-96.9$ \\
Appearance & White-to -off white, \\
& Taste on day 1,2,3,7 & Pleasant \\
& pH on day 1,2,3,7 & $6.7-6.8$ \\
& Sedimentation volume & 0.85 \\
& Assay & $96.4-96.2$ \\
\hline
\end{tabular}

Evaluation of Formulation F8 upon reconstitution at 1,2 and 3 month intervals of storage at accelerated conditions of $40 \pm 2^{\circ} \mathrm{C} / 75 \pm 5 \% \mathrm{RH}$ 
various drugs by employing techniques like hot melt extrusion (Keating et al., 2017), spray-drying (Khan et al., 2007), spray congealing (Shah et al., 2008), granulation (Albertini et al., 2004), solvent evaporation (Douroumis et al., 2011) and fluid bed coating (Amelian et al., 2017b).

We carried out a series of investigations to evaluate a suitable amount of Eudragit E100 coating to obtain $\mathrm{KCl}$ particles with optimal characteristics for the development of palatable $\mathrm{KCl}$ dry syrup formulation. We found out that $\mathrm{KCl}$ coated with coating solution containing 10\% Eudragit E100 (Composition C3 in Table 1) showed optimum $\mathrm{KCl}$ entrapment, good processability and micromeritics, and it did not lead to instantaneous release of $\mathrm{KCl}$ in buffers with $\mathrm{pH}$ values akin to the stomach as well as saliva. Hence, this was chosen for the further formulation development. Oral paediatric dose of $\mathrm{KCl}$ in the treatment of hypokalemia is $2-4 \mathrm{mEq} / \mathrm{kg} /$ day in divided doses (Potassium chloride label -FDA, 2017). The amount of coated $\mathrm{KCl}$ equivalent to $500 \mathrm{mg}$ of pure $\mathrm{KCl} / 5 \mathrm{~mL}$ was chosen as the dose for the development of dry syrup formulation.

Physical stability of a suspension formulation depends on various aspects like particle size of the dispersed phase, difference between the densities of the dispersed phase and dispersion medium as well as on the viscosity of the dispersion medium. Selection of a suitable suspending agent in optimum concentration is often the most practical approach for rendering the formulation physically stable. Various suspending agents viz. guar gum, HPMC K $100 \mathrm{LV}$, sodium carboxymethyl cellulose and Avicel CL 611were tried at equal concentration $(3.3 \% w / w)$ in formulation F1, F2, F3 and F4 respectively. Guar gum requires longer time to wet and build the viscosity and hence formulation F1 upon reconstitution showed poor viscosity resulting in greater sedimentation rate. Upon standing for a day, the formulation acquired reasonable viscosity. The formulations F2 and F3 containing HPMC K 100 LV and sodium carboxymethyl cellulose showed higher sedimentation rate and poorer redispersibility compared to the formulation F4 which contained Avicel CL 611 as a suspending agent. Avicel CL 611 comprises 82-89\% microcrystalline cellulose and $11-18 \%$ sodium carboxy methyl cellulose which offers the desired structured vehicle to the dosage form almost instantaneously upon reconstitution with water. To further improve the sedimentation ratio and redispersibility, formulations F5, F6, F7 and F8 were formulated with $6.5 \%, 10 \%, 15 \%$ and $26 \% \mathrm{w} / \mathrm{w}$ of Avicel CL 611 respectively. The sedimentation ratio increased linearly with the increment in the concentration of suspending agent and formulation F8 showed the ratio closest to unity upon keeping the suspension undisturbed over 7-day time period. The formulation redispersed homogeneously just in two inversions of the measuring cylinder holding the formulation. The overall appeal of the suspension formulation as well as the assurance of uniformity of the dosage depends on the sedimentation ratio and ease of redispersion. Sedimentation ratio closest to unity fulfils both the above criteria. Formulation F8 was thus considered as optimum and was taken up for the drug release, stability and electronic taste evaluation studies. As shown in Table 4, the in vitro release in $0.1 \mathrm{~N} \mathrm{HCl}$ was more than $95 \%$ over the $30 \mathrm{~min}$ period. The release pattern did not change on 1st, 2nd, 3rd and 7th day of reconstitution. However, release in $\mathrm{pH} 6.8$ buffer was found to increase (about $20 \%$ at the end of $30 \mathrm{~min}$ ) on day 7 as compared to $13 \%$ on the day of reconstitution. This could be attributed to leaching of the drug from the polymer coating in presence of water. Marketed syrup formulation upon subjecting to dissolution studies in $0.1 \mathrm{~N} \mathrm{HCl}$ showed complete dissolution of drug within 5 min unlike formulation F8 which could sustain the release for about $30 \mathrm{~min}$.

Taste assessment using a multichannel taste sensor, an instrument commonly named as electronic tongue (e-Tongue), is an established alternative to human sensory analysis panel. A number of pharmaceutical laboratories around the world are using this instrument to assess the unacceptable taste of drugs and the masking efficiency of various techniques. In addition, it is used in placebo development, in taste matching of formulations, and in unknown-to-reference comparisons (Rachid et al., 2010).

In the present study, the formulation F8 and the marketed syrup formulation were compared for the taste using e-Tongue. The formulation F8 showed significantly better taste-masking of $\mathrm{KCl}$ compared to the marketed syrup formulation indicating the utility of Eudragit E100 coating to improve the palatability of oral $\mathrm{KCl}$ formulations.

\section{Conclusion}

The dry syrup formulation developed using $\mathrm{KCl}$ coated with 10\% Eudragit E 100 solution could effectively mask the unpleasant taste of the drug in comparison with marketed syrup formulation as confirmed by e-Tongue testing. The in vitro release of $\mathrm{KCl}$ could not be sustained beyond $30 \mathrm{~min}$ in acidic dissolution medium owing to limitations of using higher concentrations of Eudragit during fluid bed coating operation. Combination of Eudragit $\mathrm{E}$ 100 and a water insoluble polymer like ethyl cellulose could be tried in future to retard the drug release in gastric environment to effectively avoid gastric irritation and vomiting. The taste masked $\mathrm{KCl}$ particles could also find potential applications in food industry.

\section{Abbreviations}

$\mathrm{AgNO}_{3}$ : Silver nitrate; e-Tongue: Electronic tongue; $\mathrm{HCl}$ : Hydrochloric acid; KCl: Potassium chloride; SEM: Scanning Electron Microscopy; Tg: Glass transition temperature 


\section{Acknowledgements}

The authors would like to thank S Zhaveri and Company for taste evaluation of formulations using electronic taste sensing machine. Abhijit Date would like to acknowledge support from the Jason A. Burns School of Medicine, University of Hawaii Manoa Pilot Project Grants viz. Ola HAWAll Pilot Project Grant (NIMHD Grant Number U54MD00760) and Diabetes COBRE Pilot Project Grant (NIGMS grant Number P20GM113134-02).

\section{Funding}

The present work received no funding or financial subsidy from any commercial, governmental, or other non-commercial sources.

\section{Availability of data and materials}

All data generated or analysed during this study are included in this published article.

\section{Authors' contributions}

MC conceptualized the research work, designed the formulation development strategy and overall supervised the project. SA worked on the taste masking trials of potassium chloride, dry syrup dosage form development and analysis of the formulation including stability studies. BV and SS were instrumental in optimizing the fluid bed coating process parameters for the coating trials of potassium chloride and also the analysis of the coated potassium chloride. AD was involved partly in the experimental design and drafting the manuscript and revising it critically for important intellectual content. Each one wrote the section of the paper pertaining to their respective work. All authors read and approved the final manuscript.

\section{Competing interests}

The authors declare that they have no competing interests. The contents of this manuscript have not been presented previously at any scientific conference or published in any conference proceeding.

\section{Publisher's Note}

Springer Nature remains neutral with regard to jurisdictional claims in published maps and institutional affiliations.

\section{Author details}

'Department of Pharmaceutics, SCES's Indira College of Pharmacy, 89/2a, Niramay, New Mumbai Pune Highway, Tathawade, Pune, Maharashtra 411033, India. ${ }^{2}$ Gansons Ltd, Kolshet Road, Manpada, Thane, Maharashtra 400607, India. ${ }^{3}$ Department of Pharmaceutical Sciences, The Daniel K. Inouye College of Pharmacy, University of Hawaii Hilo, 200 W. Kawili Street, Hilo, HI 96720, USA.

Received: 6 September 2018 Accepted: 7 January 2019

Published online: 22 January 2019

\section{References}

Albertini B, Cavallari C, Passerini N, Voinovich D, González-Rodrıguez ML, Magarotto L, Rodriguez L (2004) Characterization and taste-masking evaluation of acetaminophen granules: comparison between different preparation methods in a high-shear mixer. Eur J Pharm Sci 21:295-303. https://doi.org/10.1016/j.ejps.2003.10.017

Amelian A, Szekalska M, Ciosek P, Basa A, Winnicka K (2017a) Characterization and taste masking evaluation of microparticles with cetirizine dihydrochloride and methacrylate based copolymer obtained by spray drying. Acta Pharma 67:113-124. https://doi.org/10.1515/acph-2017-0002

Amelian A, Wasilewska K, Wesoły M, Ciosek-Skibińska P, Winnicka K (2017b) Tastemasking assessment of orally disintegrating tablets and lyophilisates with cetirizine dihydrochloride microparticles. Saudi Pharm J 25:1144-1150. https://doi.org/10.1016/j.jsps.2017.06.001

Aulton ME (2013) Powder flow. In: Aulton ME, Taylor KM (eds) Aulton's Pharmaceutics, The design and manufacture of medicines, 4thedn edn. Churchill Livingstone, China, pp 187-199

Chang RK, Rudnic EM (1991) The effect of various polymeric coating systems on the dissolution and tableting properties of potassium chloride microcapsules. Int J Pharm 70:261-270. https://doi.org/10.1016/0378-5173(91)90290-5

CIMS (Current Index of Medical Specialties) (2017); Bengaluru (India): CIMS Medica India; p. 448
Cohn JN, Kowey PR, Whelton PK, Prisant LM (2000) New guidelines for potassium replacement in clinical practice: a contemporary review by the national council on potassium in clinical practice. Arch Intern Med 160:2429-2436. https://doi.org/10.1001/archinte.160.16.2429

Dinge A, Nagarsenker M (2008) Formulation and evaluation of fast dissolving films for delivery of triclosan to the oral cavity. AAPS PharmSciTech 9:349356. https://doi.org/10.1208/s12249-008-9047-7

Douroumis DD, Gryczke A, Schminke S (2011) Development and evaluation of cetirizine $\mathrm{HCl}$ taste-masked oral disintegrating tablets. AAPS PharmSciTech12: 141-151. https://doi.org/10.1208/s12249-010-9569-7

Faisal W, Faraq F, Abdellatif AA, Abbas A (2018) Taste masking approaches for medicines. Curr Drug Deliv 15:167-185. https://doi.org/10.2174/ 1567201814666171013145958

Gennari FJ (1998) Hypokalemia. New Eng J Med 339:451-458. https://doi.org/10. 1056/NEJM199808133390707

Ghimire M, Mahmoudi ZN, Teckoe J, Rajabi-Siahboomi A (2018) Application of a pH dependent taste-mask film coating for pediatric multiparticulate formulations. Int J Pharm 536:498-511. https://doi.org/10.1016/j.jpharm.2017.08.021

Graham DY, Lacey Smith JL, Bouvet AA (1990) What happens to tablets and capsules in the stomach: endoscopic comparison of disintegration and dispersion characteristics of two microencapsulated potassium formulations. J Pharm Sci 79:420-424. https://doi.org/10.1002/jps.2600790512

Indian Pharmacopeia (2014) vol 2. Indian Pharmacopoeial commission, Ghaziabad, p. 811, 2520.

Karaman R (2013) Prodrugs for masking bitter taste of antibacterial drugs- a computational approach. J Mol Model 19:2399-2412. https://doi.org/10.1007/ s00894-013-1780-5

Kaushik D, Dureja H (2014) Recent patents and patent technology platforms for pharmaceutical taste masking. Recent Pat Drug Deliv Formul 8:37-45. https:// doi.org/10.2174/1872211308666140206150840

Keating AV, Soto J, Tuleu C, Forbes C, Zhao M, Craig D (2017) Solid state characterisation and taste masking efficiency evaluation of polymer based extrudates of isoniazid for paediatric administration. Int J Pharm. https://doi. org/10.1016/j.ijpharm.2017.07.008

Keser S, Timpe C, Zimmer A (2018) Development and evaluation of taste-masked pediatric minitablet formulations with bitter model drugs. Int J Pharm 536: 512-526. https://doi.org/10.1155/2014/789676.

Khan S, Kataria P, Nakhat P, Yeole P (2007) Taste masking of ondansetron hydrochloride by polymer carrier system and formulation of rapiddisintegrating tablets. AAPS PharmSciTech 8:127-133. https://doi.org/10. 1208/pt0802046.

Khar RK, Vyas SP, Ahnad FJ, Jain GK (2013) The theory and practice of industrial pharmacy, 4thedn. CBS, New Delhi, pp 671-672

Kouchak M, Ramezani Z, Bagheri F (2018) Preparation and evaluation of taste masking iron suspension: taking advantage of weak cationic exchange resin. AAPS PharmSciTech19:719-729. Doi: https:/doi.org/10.1208/s12249-017-0881-3.

Kumar CP, Rao KM, Saravanan D, Padmavathy J, Kumar CP, Lakshmi IA (2011) Formulation and evaluation of potassium chloride extended release capsules. J Pharm Res 4:2529-2532

Latha RS, Lakshmi PK (2012) Electronic tongue: an analytical gustatory tool. J Adv Pharm Technol Res 3:3-8. https://doi.org/10.4103/2231-4040.93556.

Lorenz JK, Reo JP, Hendl O, Worthington JH, Petrossian VD (2009) Evaluation of a taste sensor instrument (electronic tongue) for use in formulation development. Int J Pharm 367:65-72. https://doi.org/10.1016/j.jpharm.2008.09.042

Mahesh A, Shastri N, Sadanandam M (2010) Development of taste masked fast disintegrating films of levocetirizine dihydrochloride for oral use. Curr Drug deliv 7(1):21-27. https://doi.org/10.2174/156720110790396454

Malik K, Arora G, Singh I (2011) Taste masked microspheres of ofloxacin: formulation and evaluation of orodispersible tablets. Sci Pharm 79:653-672. https://doi.org/10.3797/scipharm.1104-11

Maniruzzaman M, Boateng JS, Bonnefille M, Aranyos A, Mitchell JC, Douroumis D (2012) Taste masking of paracetamol by hot-melt extrusion: an in vitro and in vivo evaluation. Eur J Pharm and Biopharm 80:433-442. https://doi.org/10. 1016/j.ejpb.2011.10.019

Mcmahon FG, Akdamar K, Ryan J, Ertan A (1982) Upper gastrointestinal lesions after potassium chloride supplements: a controlled clinical trial. Lancet 320: 1059-1061. https://doi.org/10.1016/S0140-6736(82)90002-2

Mittapalli RK, Marroum P, Qiu Y, Apfelbaum K, Xiong H (2017) Development of in vitro - in vivo correlation for potassium chloride extended release tablet formulation using urinary pharmacokinetic data. Pharm Res 34:1527-1533. https://doi.org/10.1007/s11095-017-2179-2 
Pawar HA, Joshi PR (2014) Development and evaluation of taste masked granular formulation of satranidazole by melt granulation technique. J Pharm 2014:1-7. https://doi.org/10.1155/2014/789676

Pimparade MB, Marrott JT, Park JB, Kulkarni VI, Majumdar S, Murthy SN (2015)

Development of taste masked caffeine citrate formulations utilizing hot melt extrusion technology and in vitro- in vivo evaluations. In J Pharm 487:167176. https://doi.org/10.1016/j.jpharm.2015.04.030

Potassium chloride label - FDA (2017), https://www.accessdata.fda.gov/ drugsatfda_docs/label/2014/206814lbl.pdf. Accessed 12 Jun 2017.

Prabhakaran R, Janakiraman K, Harindran J (2016) Formulation and evaluation of taste masked oral suspension of cefuroxime axetil using hydroxy propyl beta cyclodextrin. Asia J Pharm Clin Res 9:90-92

Rachid O, Simons FE, Rawas-Qalaji M, Simons KJ (2010) An electronic tongue: evaluation of the masking efficacy of sweetening and/or flavoring agents on the bitter taste of epinephrine. AAPS PharmSciTech11:550-557. https://doi. org/10.1208/s12249-010-9402-3

Rowe RC, Sheskey PJ, Weller PJ (eds) (2009) Handbook of pharmaceutical excipients, 5thedn. Pharmaceutical, London

Shah PP, Mashru RC, Rane YM, Thakkar A (2008) Design and optimization of mefloquine hydrochloride microparticles for bitter taste masking. AAPS PharmSciTech9:377-389. https://doi.org/10.1208/s12249-008-9052-x

Shen RW (1996) Taste masking of ibuprofen by fluid bed coating. US patent 5,552,152,3Sept1996.

Stange U, Führling C, Gieseler H (2014) Taste masking of naproxen sodium granules by fluid-bed coating. Pharm Dev Technol 19:137-147. https://doi. org/10.3109/10837450.2012.757784

Thoke SB, Gayke A, Dengale R, Patil P, Sharma Y (2012) Review on: taste masking approaches and evaluation of taste masking. Int J Pharm Sci 4:1895-1907

Wu PC, Huang YB, Chang JS, Tsai MJ, Tsai YH (2003) Design and evaluation of sustained release microspheres of potassium chloride prepared by Eudragit ${ }^{\oplus}$. Eur J Pharm Sci 19:115-122. https://doi.org/10.1016/S0928-0987(03)00069-1

\section{Submit your manuscript to a SpringerOpen ${ }^{\circ}$ journal and benefit from:}

- Convenient online submission

- Rigorous peer review

- Open access: articles freely available online

- High visibility within the field

- Retaining the copyright to your article

Submit your next manuscript at $\boldsymbol{\nabla}$ springeropen.com 